\title{
Prodynorphin- and substance P-containing neurons project to the medial preoptic area in the male Syrian hamster brain
}

\author{
Charles R. Neal, Jr. and Sarah Winans Newman \\ Department of Anatomy and Cell Biology, University of Michigan Medical School, Ann Arbor, MI (U.S.A.)
}

(Accepted 30 October 1990)

Key words: Dynorphin; Substance P; Leumorphin; Tract tracing; Fluoro-gold; Latex microsphere; Opiate

\begin{abstract}
To determine if substance $\mathrm{P}$ - or prodynorphin-containing neurons of the medial nucleus of the amygdala and medial bed nucleus of the stria terminalis send projections to the medial preoptic area in the male Syrian hamster, we placed a fluorescent retrograde tract tracer (either Fluoro-gold, or rhodamine- or fluorescein-impregnated latex microspheres) into the medial preoptic area. Five to seven days later, the animals were treated with colchicine, allowed to survive for $48 \mathrm{~h}$ and the brains were processed for immunofluorescence histochemistry. Tissue sections were incubated in either rat anti-substance $P$ or rabbit anti-C-peptide (the C-terminal sequence of dynorphin $B_{1-29}$ ) antiserum followed by incubation in either fluorescein-or rhodamine-conjugated anti-rabbit or anti-rat antiserum. When the injection site of retrograde tracer was centered within the caudal one-third of the medial preoptic area, labeled cell bodies were observed caudally in the medial part of the bed nucleus of the stria terminalis. Retrogradely labeled cell bodies were also observed in the posterodorsal subdivision of the medial nucleus of the amygdala. Both prodynorphin and substance $\mathrm{P}$ immunolabeling were observed in retrogradely labeled neurons in these two areas but fewer of these projection neurons were immunolabeled with substance $P$ antiserum than with C-peptide antiserum. These projections may play a role in the peptidergic modulation of reproductive behavior in this species.
\end{abstract}

\section{INTRODUCTION}

Several neuropeptides have been implicated as possible modulators of male rodent sexual behavior, including the dynorphins ${ }^{1,20,38}, \beta$-endorphin ${ }^{36,37,41,42}$, substance $\mathrm{P}^{10,60}$ and gonadotropin-releasing hormone ${ }^{11}$. We have recently identified opioid peptides and substance $P$ in neurons of the chemosensory pathways which control mating behavior in the male Syrian hamster. Specifically, the endogenous opioid peptides dynorphin A, dynorphin $\mathrm{B}$ and leumorphin have been observed within numerous cell bodies, fibers and terminals in the medial nucleus of the amygdala, medial bed nucleus of the stria terminalis and the medial preoptic area in this species ${ }^{44}$. In contrast, these same nuclei contain only minute amounts of prodynorphin peptides in the rat ${ }^{12,44}$. Numerous substance P-containing neurons have also been observed within these three structures in the hamster chemosensory system ${ }^{58}$, and many of these neurons contain both substance $\mathrm{P}$ and dynorphins ${ }^{43}$.

In contrast to the inhibitory role traditionally ascribed to endogenous opioids in male copulatory behavior, there is increasing evidence that prodynorphin peptides may actually be facilitating this behavior ${ }^{1,20,38,53}$. Substance $P$ has also been shown to facilitate male sexual behavior ${ }^{10}$, and the level of this neuropeptide in chemosensory pathway nuclei is regulated by gonadal steroids in the male hamster ${ }^{58}$.

The present study tests the hypothesis that dynorphinor substance P-containing neurons within the medial nucleus of the amygdala or medial bed nucleus of the stria terminalis project to the region within the caudal medial preoptic area where lesions eliminate male copulatory behavior ${ }^{51}$. We did not systematically search the brain for all sources of substance P- and dynorphincontaining afferents to the medial preoptic area, although analyses of 3 additional areas are reported for comparison with our observations on this chemosensory pathway.

\section{MATERIALS AND METHODS}

\footnotetext{
Animals

Forty-four adult male Syrian hamsters (Mesocricetus auratus) weighing $120-125 \mathrm{~g}$ were used in this study. All hamsters were purchased from Charles River, maintained on a 14:10 (L:D) illumination cycle and given food and water ad libitum. These animals were used in a multifaceted study of the projections of $\beta$-endorphin-, substance $\mathrm{P}$ - and prodynorphin-containing neurons into the medial preoptic area.
} 


\section{Fluorescent retrograde tract tracer}

Fluoro-gold (FG; Fluorochrome Inc.; Englewood, $\mathrm{CO}$ ) was prepared as a $1-2 \%$ solution in $0.1 \mathrm{M}$ acetic acid $(\mathrm{pH} 3.0-3.3)$. Animals were anesthetized with sodium pentobarbitol $(10 \mathrm{mg} / 100 \mathrm{~g}$ body weight) and the tracer was iontophoresed into the caudal medial preoptic area using an angled, contralateral stereotaxic approach to avoid damage to fibers ipsilateral to the injection (2-3 $\mu \mathrm{A} ; 7 \mathrm{~s}$ on $/ 7 \mathrm{~s}$ off; $30-45 \mathrm{~min}$; pipette tip inside diameter $=30-45$ $\mu \mathrm{m})$.

The protocol of Katz and Iarovici ${ }^{28}$ was used for injection of the rhodamine- or fluorescein-impregnated latex microspheres (LumaFluor Inc., New City, NY). A micropipette (inside tip diameter = $30-45 \mu \mathrm{m}$ ) was filled to the shank with latex beads, sealed to the needle of a $5-\mu 1$ Hamilton syringe with paraffin wax, stereotaxically lowered into the medial preoptic area using the contralateral approach, and left in place for $10 \mathrm{~min}$. The tracer was then injected into the brain parenchyma and, after an additional $15 \mathrm{~min}$, the pipette was removed.

Five to seven days after tracer injection, animals were reanesthetized and colchicine was injected into the lateral ventricle ipsilateral to the tracer injection site ( $2 \mu \mathrm{l}$ of $80 \mu \mathrm{g} / \mu \mathrm{l}$ colchicine) After $48 \mathrm{~h}$ the animals were perfused and their brains processed for immunohistochemistry. Animals receiving FG $(n=23)$ were perfused with $4 \%$ paraformaldehyde, and animals injected with latex beads $(n=21)$ were perfused with $2 \%$ paraformaldehyde + $0.25 \%$ benzoquinone.

Tissue sections from FG-treated brains were mounted on gelatincoated slides, air-dried, briefly dehydrated, cleared in xylenes and coverslipped with the mountant DPX. Tissue sections with latex microspheres were simply air-dried and coverslipped with DPX because alcohols dissolve the microspheres. Adjacent sections were stained with cresyl violet for cytoarchitectonic localization of labeled cells.

\section{Immunohistochemistry}

Antisera. The leumorphin polyclonal antiserum used in this study (no. 109, bleed 6) was generated in rabbit and is directed against the 14-amino acid C-terminal sequence of the rat prodynorphin molecule. This ' $C$-peptide' sequence corresponds to the $C$-terminus of dynorphin $\mathrm{B}_{1-29}$ (also known as leumorphin). This antiserum was generously provided by Dr. Stanley J. Watson, Jr., Mental Health Research Institute, University of Michigan. The substance $\mathrm{P}$ probe was a monoclonal antiserum generated in rat and purchased from Sera-Lab (Accurate Scientific).

Immunofluorescence histochemistry. The indirect immunofluorescence procedure used in this study has been described elsewhere ${ }^{43}$ 55,56 . Brain tissues were washed in $0.022 \mathrm{M}$ potassium phosphatebuffered saline (KPBS) and transferred to either substance $P$ or leumorphin antiserum (1:500 in 0.3\% Triton-X in KPBS) for 48-60 $h$. Sections were then washed and incubated in a secondary antiserum for $1 \mathrm{~h}$. With tissue from brains injected with rhodamineimpregnated latex microspheres, fluorescein isothiocyanate (FITC)conjugated donkey anti-rabbit antiserum was used for leumorphin immunostaining and FITC-conjugated anti-rat antiserum was used for substance $\mathrm{P}$ immunostaining (both at $1: 50$ in $0.3 \%$ Triton- $\mathrm{X}$ in KPBS). With tissue from brains injected with fluorescein-impregnated latex microspheres or FG, we used rhodamine isothiocyanate (RITC)-conjugated donkey anti-rabbit antiserum for leumorphin immunostaining and RITC-conjugated anti-rat antiserum for substance $P$ immunostaining (both at $1: 25$ in $0.3 \%$ Triton- $X$ in KPBS). All secondary antisera were purchased from Jackson Laboratories. Following secondary incubation, the sections were washed 6-10 times in distilled water, mounted on gelatin-coated slides, air-dried and coverslipped with DPX (for RITC immunolabeling) or glycerolphosphate buffer medium containing phenylenediamine for optimal preservation of FITC immunofluorescence ${ }^{21,50}$

Immunocytochemistry controls. The leumorphin and substance $\mathrm{P}$ antibodies have been characterized in detail previously ${ }^{43.55,56}$. Briefly, the substance $\mathbf{P}$ and leumorphin antisera were individually incubated for $1 \mathrm{~h}$ at room temperature with their respective peptides, either $25 \mu \mathrm{M}$ substance $\mathrm{P}$ peptide (Penninsula Labs) or $5-10 \mu \mathrm{M}$ rat C-terminus peptide (generously donated by Dr. Stanley J. Watson, Ir.). In other experiments, the antisera were also pre-incubated with $50-100 \mu \mathrm{M}$ of either porcine C-terminus, human leumorphin, dynorphin B [1-13], dynorphin A [1-17]. dynorphin A [1-13] or leu-enkephalin peptides (Penninsula Labs) prior to tissue incubation. Additionally, sections were incubated with KPBS in place of primary antiserum, followed by $1 \mathrm{~h}$ with secondary antiserum, to check for non-specific background staining elicited by donkey antisera recognizing epitopes in the hamster brain.

All primary antisera, with or without blocking peptides added. were left at room temperature for $1 \mathrm{~h}$ prior to the beginning of incubation. Thus, antisera with no peptides added for blocking controls were treated identically to those in which the peptides were allowed an hour for preabsorption

Analysis of tissues. Sections were analyzed with a Leitz Aristoplan fluorescence microscope, using filter system $\mathrm{I} 2(450-490 \mathrm{~nm}$ blue light excitation) to induce green-blue emission from FITC-immunolabeling and green emission from fluorescein-impregnated microspheres, filter system $\mathrm{N} 2(530-560 \mathrm{~nm}$ green light excitation) to induce red emission from RITC-immunolabeled elements and rhodamine-impregnated microspheres, and filter system A (340-380 $\mathrm{nm}$ narrow band blue excitation) to induce yellow-gold emission from $F G$.

In brains with tracer injection sites confined to the caudal medial preoptic area, the number of single- and double-labeled cells were counted in select microscopic fields containing both immunolabeled and retrogradely labeled cell bodies within the medial bed nucleus of the stria terminalis and medial nucleus of the amygdala. All labeled neurons were counted using a hand-held counter. Tracers transported from terminals within the medial preoptic area accumulated within the cytoplasm and processes of the retrogradely labeled neurons. FG-filled neurons contained fine yellow-gold granules, whereas the transported latex microspheres, ranging from 20 to $50 \mathrm{~nm}$ in diameter ${ }^{18}$, filled neuronal cytoplasm and processes with coarse granules emitting bright red (rhodamine) or green (fluorescein) fluorescence. A cell was considered double-labeled if it contained granules of tracer in its cytoplasm under one excitation filter and displayed homogeneous cytoplasmic fluorescence for either FITC or RITC under a different excitation filter. The number of double-labeled cells within a field was divided by the total number of substance $\mathrm{P}$ - or leumorphin-containing cells counted in that field. These proportions are reported in an attempt to convey more accurately, in this descriptive study, the magnitude of the substance $\mathrm{P}$ - or leumorphin-containing projections arising from the areas described

\section{RESULTS}

\section{Tract tracing}

Tracer comparisons. Injections confined to the medial part of the caudal medial preoptic area produced similar retrograde labeling patterns regardless of the tracer used. This area is limited rostrally by the posterior border of the body of the anterior commissure, and caudally, by the anterior border of the suprachiasmatic nucleus. Lesions in this area disrupt mating behavior in both the rat and hamster ${ }^{15,51}$

Fluoro-gold iontophoresis produced a spherical injection site (Fig. 1A), approximately $1 \mathrm{~mm}$ in diameter, with a small necrotic center $(50-100 \mu \mathrm{m}$ in diameter). The latex microspheres produced a site resembling a deposit of beads at the end of the micropipette trajectory (Fig. 

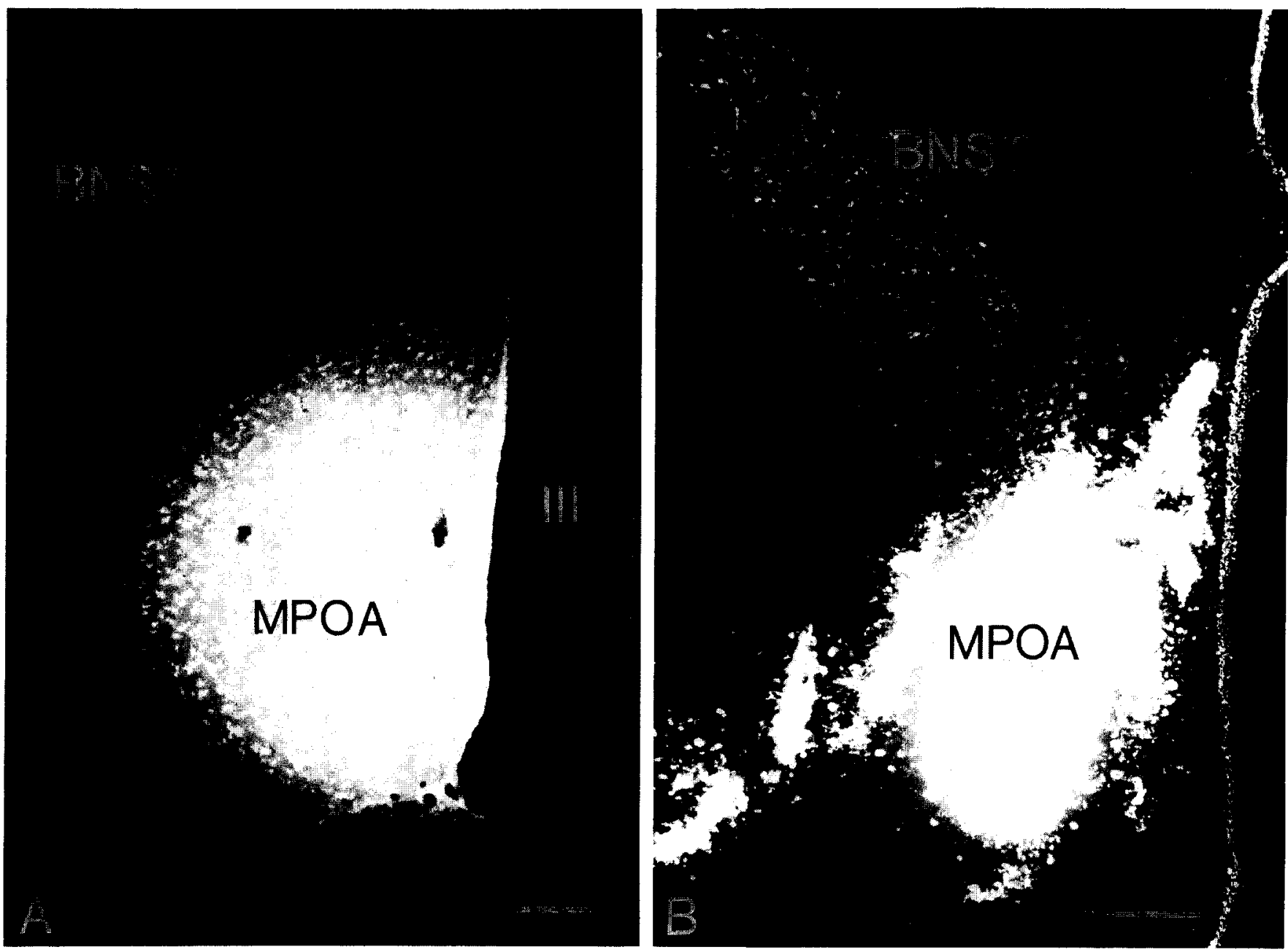

Fig. 1. Fluorescence photomicrographs demonstrating an FG iontophoresis site (A), and a rhodamine microsphere injection site (B) in the caudal medial preoptic area of 2 different male hamsters. Calibration bars equal $100 \mu \mathrm{m}$.

1B) with little diffusion of beads from the injection center and no central necrosis.

Fluoro-gold is reportedly not taken up by fibers of passage ${ }^{49,54}$. In contrast, the fluorescent microspheres are reported to be taken up and transported, but only by damaged fibers ${ }^{27}$. These observations in the rat are supported by our observations in the hamster. When the FG iontophoresis site was within the anterior commissure, no retrograde labeling was observed in the anterior olfactory nucleus or other ventral forebrain structures known to project through this bundle. On the other hand, when rhodamine or fluorescein beads were injected into the anterior commissure or rostral fornix, numerous retrogradely labeled neurons were observed within the anterior olfactory nucleus and hippocampal formation, respectively. With both microspheres and FG, when the injection site was not within the fiber tract, but rather, in the gray matter adjacent to it, no transport was observed to the anterior olfactory nucleus (for anterior commissure injections) or the hippocampal formation (for fornix injections).
Although FG has been used in combination with immunocytochemistry in the rat $^{22,61}$, we were unable to control quenching of FG fluoresence in combination with this technique on hamster brain tissue. Therefore, brains with FG injections were used only for retrograde transport studies and as a basis for interpretation of transport from microsphere injection sites. Brains containing the fluorescent microspheres were utilized for the combined studies with immunohistochemistry. In order to prevent microsphere-containing pipettes from penetrating ipsilateral fiber bundles, the contralateral approach to the medial preoptic area was used and retrograde labeling was analyzed only on the side ipsilateral to the injection site.

Distribution of cells projecting to the medial preoptic area from the medial bed nucleus of the stria terminalis and medial nucleus of the amygdala. Ipsilateral to the injection site, both FG and rhodamine-impregnated microspheres produced patterns of retrograde labeling similar to the pattern described for medial preoptic nucleus afferents in the rat ${ }^{5,57}$. Injection sites used in this analysis were confined to the caudal medial preoptic area 
(Fig. 1). A schematic representation of an injection site centered in the medial half of the caudal medial preoptic area and the distribution of retrogradely labeled neurons projecting into this injection site is illustrated in Figs. 2 and 3. Retrogradely labeled cell bodies were observed rostrally in the infralimbic cortex, intermediate and ventral lateral septum, vertical limb of the diagonal band of Broca, nucleus accumbens, rostral medial preoptic area, parataenial nucleus of the thalamus, subfornical organ and medial bed nucleus of the stria terminalis. Caudal to the injection site, heaviest retrograde labeling was observed in the preoptic bed nucleus of the stria terminalis, numerous hypothalamic nuclei (particularly the arcuate and ventral premammillary nuclei), anterior cortical and medial nuclei of the amygdala, amygdalohippocampal area, subiculum, periaqueductal gray, dorsal raphe and peri-peduncular nucleus.

Projections from the medial bed nucleus of the stria terminalis to the medial preoptic nucleus have been reported in the rat ${ }^{5,57}$ but not in the hamster. Tracer injections centered within the male hamster caudal medial preoptic area labeled numerous neurons in the medial part of the bed nucleus of the stria terminalis throughout its extent (Figs. 2A-E; 4A). They were most numerous in the dorsal part of this nucleus at mid-caudal and caudal levels, extending ventrally to lie adjacent to the fornix and stria medullaris. In the most caudal regions, retrogradely labeled cells also filled the preoptic bed nucleus of the stria terminalis (Fig. 2E).

Projections from the medial nucleus of the amygdala to the medial preoptic area have been reported in the male hamster ${ }^{29,35}$. Results of the present study concur with earlier findings. Medial nucleus neurons with projections to the caudal one-third of the medial preoptic area were confined to the caudal region of the posterodorsal subdivision of this nucleus (Figs. 3A-D; 4B-C).

Leumorphin- and substance P-containing projection neurons in the medial bed nucleus of the stria terminalis and medial nucleus of the amygdala

Substance $\mathbf{P}$ and leumorphin distribution in the medial preoptic area, medial bed nucleus of the stria terminalis and medial nucleus of the amygdala have been described in detail for the male Syrian hamster ${ }^{43,44}$. After immu-
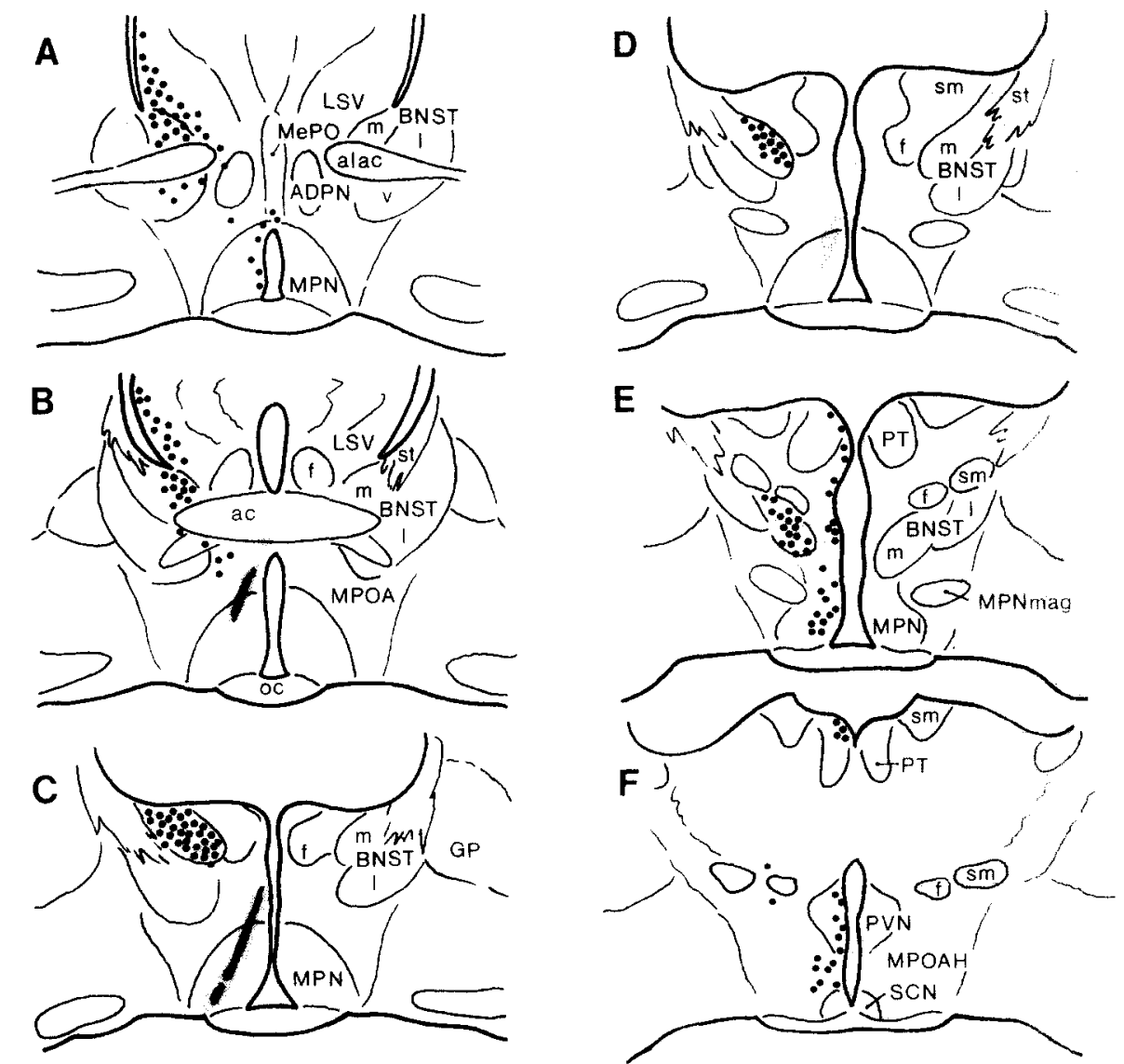

Fig. 2. Schematic drawings of coronal sections of the hamster brain through the medial preoptic area and bed nucleus of the stria terminalis illustrating the injection site centered in the caudal medial preoptic area and the pattern of distribution of retrogradely labeled neurons in hamster FN155. Black circles represent the distribution of retrogradely labeled cell bodies and the biackened area with gray shading represents the injection center. 

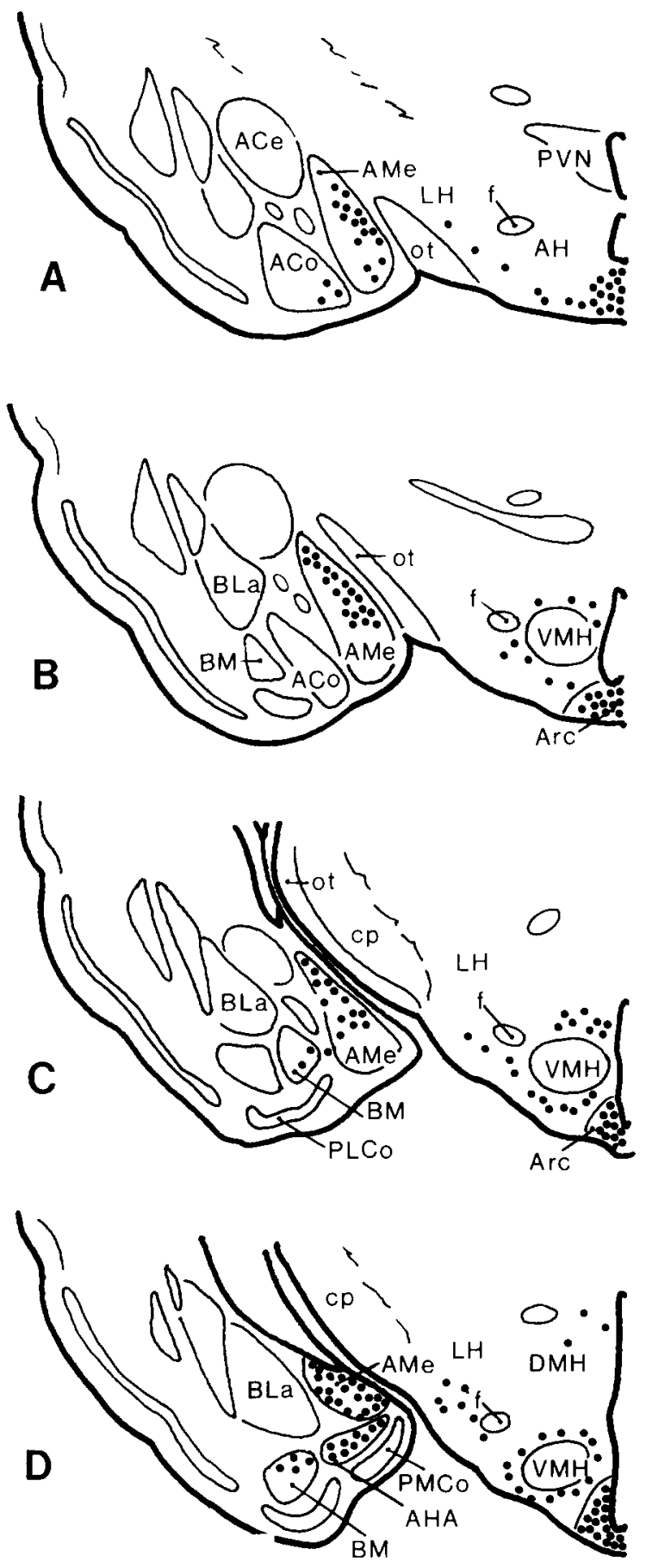

Fig. 3. Schematic drawings of coronal sections of the hamster brain through the medial nucleus of the amygdala and hypothalamus illustrating the pattern of distribution of retrogradely labeled neurons from the injection site in FN155 [Fig. 2]. Black circles represent the distribution of retrogradely labeled cell bodies.

Fig. 4. Fluorescence photomicrographs of retrogradely labeled cell bodies in the medial bed nucleus of the stria terminalis (A) and medial nucleus of the amygdala (B) after FG iontophoresis into the caudal medial preoptic area. The photograph in $(\mathrm{C})$ is a high power view of FG-containing neurons seen in $\mathrm{B}$. Calibration bars equal 100 $\mu \mathrm{m}(\mathrm{A}, \mathrm{B})$ and $50 \mu \mathrm{m}(\mathrm{C})$.
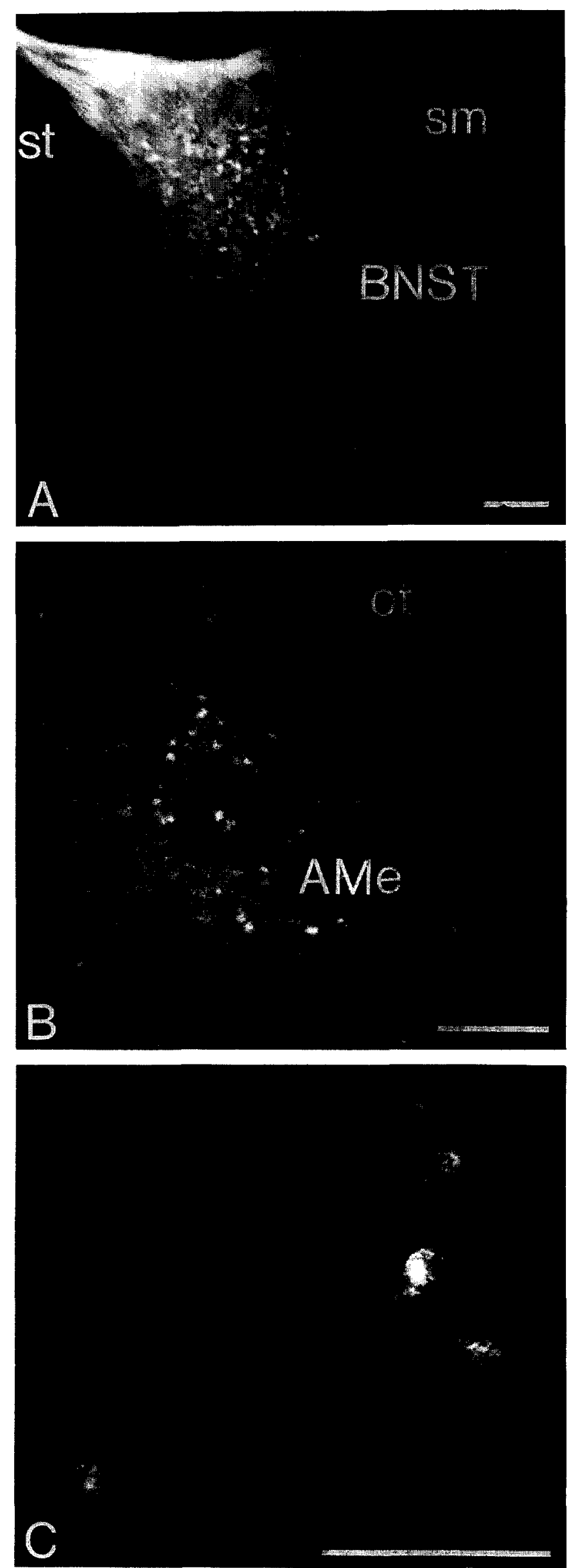
nolabeling sections from brains with retrograde tracer injections centered in the caudal medial preoptic area, double-labeled leumorphin-containing cell bodies were observed in the medial bed nucleus of the stria terminalis and medial nucleus of the amygdala (Fig. 5A,B), and double-labeled substance P-containing cell bodies were found in these same areas (Fig. 5C,D). Double-labeled neurons made up a small percentage of the total substance $\mathrm{P}$ or leumorphin populations in these areas.

It should be noted that the patterns of substance P- and leumorphin-containing projection neurons were similar. This was expected because both leumorphin and substance $\mathbf{P}$ have been described in the same areas of the hamster brain ${ }^{44,58}$, and these peptides have been colocalized within the same neurons in these structures ${ }^{43}$. However, the percentage of substance P-containing neurons with MPOA projections was consistently less than the percentage of leumorphin-containing projection neurons in both the medial nucleus of the amygdala and medial bed nucleus of the stria terminalis.

Medial bed nucleus of the stria terminalis. In the rostral bed nucleus of the stria terminalis, between the lateral ventricle and body of the anterior commissure, leumorphin-containing neurons were situated laterally and retrogradely labeled neurons medially. No region of overlap existed. However, immediately ventral to the body of the
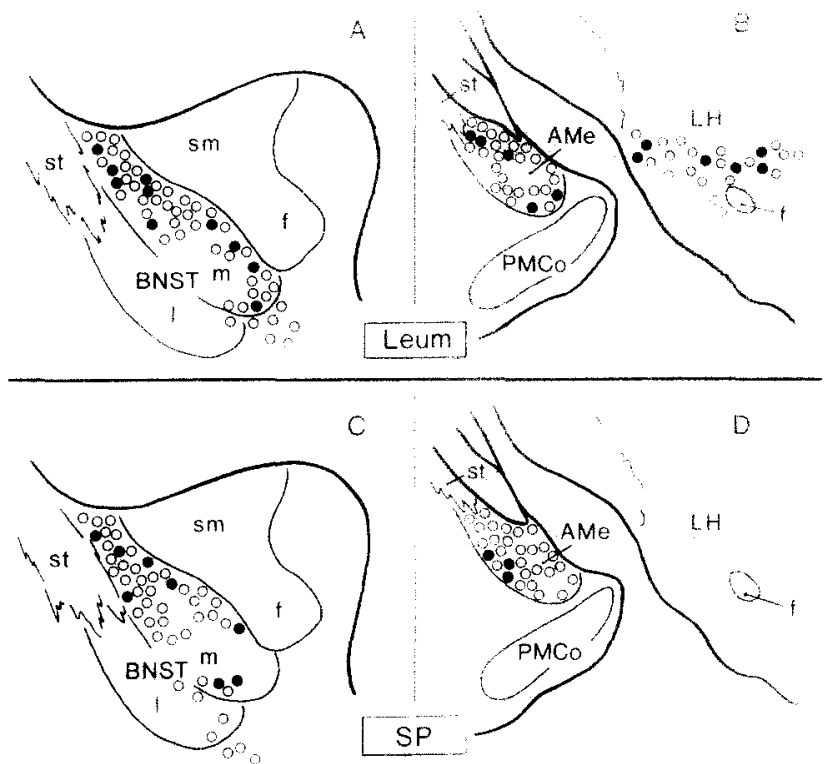

Fig. 5. Schematic drawings of coronal sections of the hamster brain through the bed nucleus of the stria terminalis $(A, C)$, and the medial nucleus of the amygdala and lateral hypothalamus $(B, D)$ Open circles $(O)$ represent the distribution of leumorphin-containing (A,B) and substance P-containing (C,D) neurons. Closed circles (O) indicate leumorphin-containing or substance $P$-containing neurons double labeled with retrograde tracer after injection in the caudal medial preoptic area.

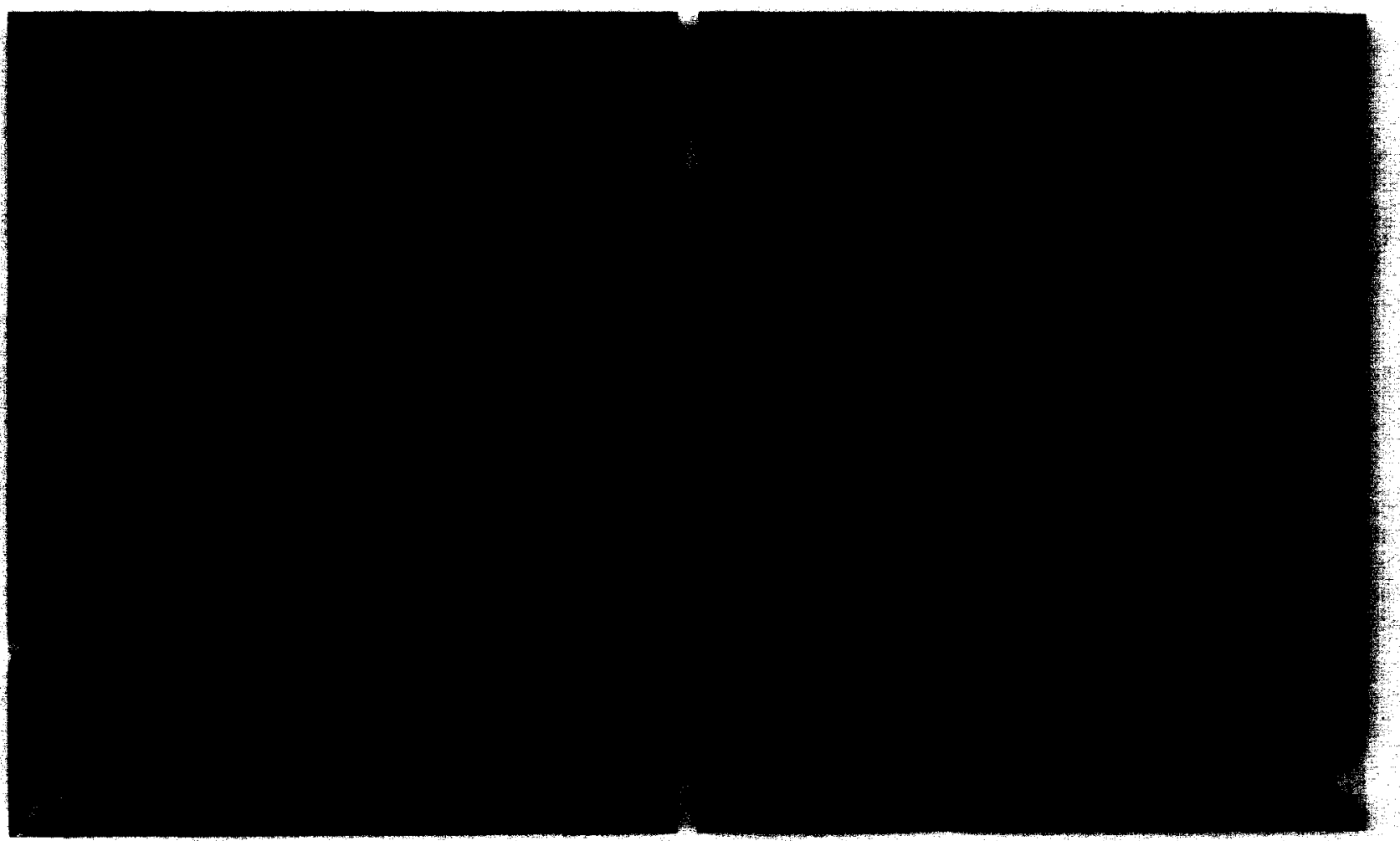

Fig. 6. Fluorescence photomicrograph of retrogradely labeled cell bodies in the medial bed nucleus of the stria terminalis following injection of fluorescein-impregnated latex microspheres into the caudal medial preoptic area (A). This same section was immunolabeled for substance $\mathrm{P}$ using an RITC-conjugated secondary antiserum (B). Double-labeled neurons are indicated by arrows. Calibration bar equals $50 \mu \mathrm{m}$. 
anterior commissure, $3-5 \%$ of the leumorphin-containing neurons were double labeled. At mid-caudal levels of the bed nucleus, a dense population of leumorphin-containing cell bodies overlapped with the retrogradely labeled neurons filling the medial subdivision dorsally adjacent to the lateral ventricle, and ventrally adjacent to the fornix and stria medullaris (Fig. 5A). In this area, $7-11 \%$ of the leumorphin-containing neurons were observed to be double labeled. The majority of these double-labeled cells were located ventrally, along the stria medullaris and fornix. At caudal levels, in the preoptic bed nucleus of the stria terminalis, leumorphincontaining and retrogradely labeled neuronal populations also overlapped extensively and the proportion of leumorphin neurons which were double labeled was relatively unchanged $(7-13 \%)$. In the most caudal part of the preoptic bed nucleus both leumorphin and tracer labeling decreased dramatically and no double-labeled cells were observed.

Rostrally, substance P-containing neurons in the bed nucleus of the stria terminalis were scattered dorsal and ventral to the body of the anterior commissure but no double-labeled neurons were found. At mid-caudal levels a dense population of substance P-containing neurons with a pattern of distribution similar to that described above for leumorphin filled the medial subdivision. In this population, $5-6 \%$ of substance P-containing neurons were double labeled (Figs. 5C; 6). Like the leumorphincontaining projection neurons, these substance P-containing double-labeled cells were situated predominantly in the ventromedial portion of the nucleus, adjacent to the stria medullaris and fornix. Only an occasional double-labeled cell body was observed in the dorsal part of the medial subdivision, even though the populations of
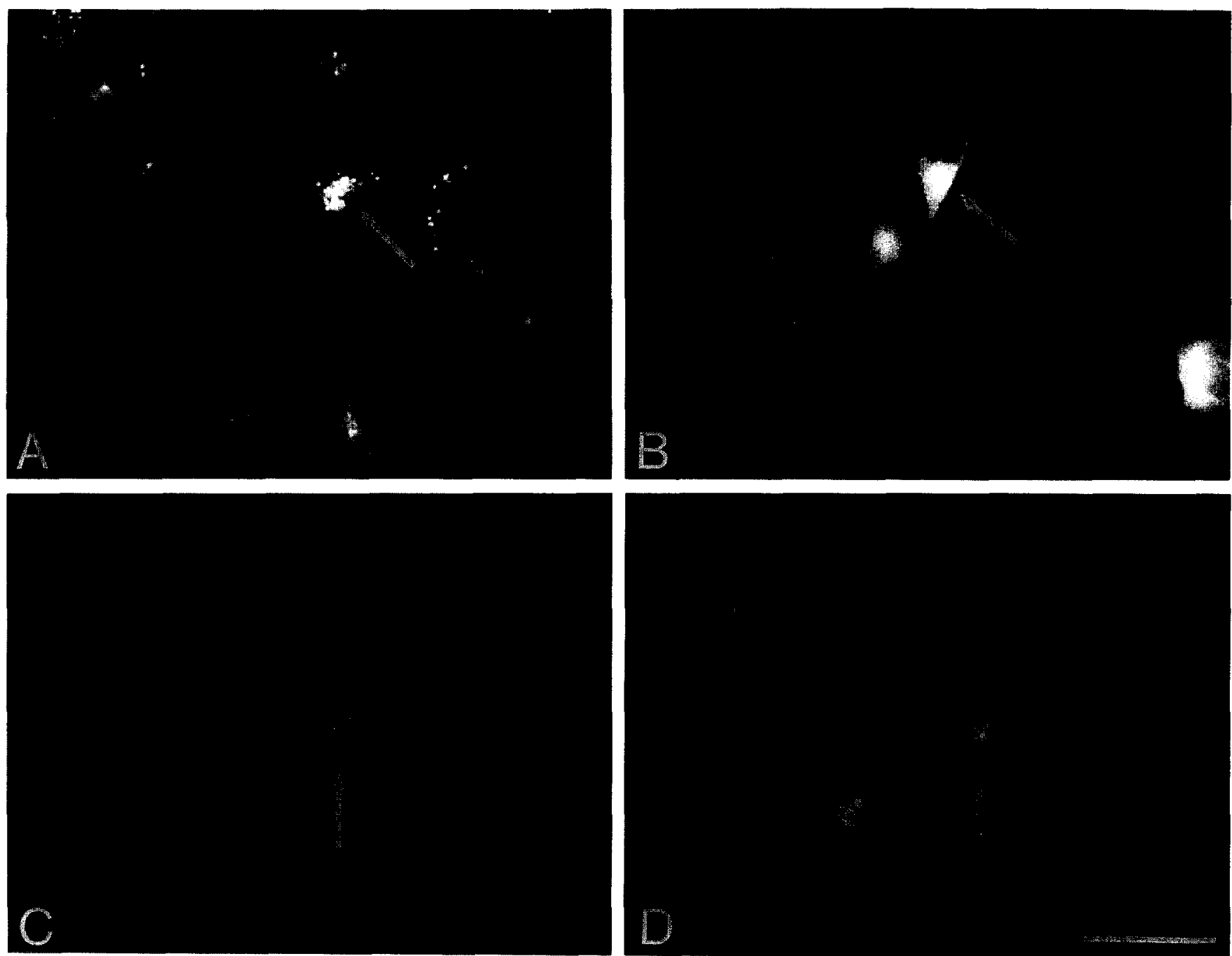

Fig. 7. Fluorescence photomicrographs of retrogradely labeled cell bodies in the medial nucleus of the amygdala (A) and lateral hypothalamus (C) following injection of rhodamine-impregnated latex microspheres into the caudal medial preoptic area. These same sections were labeled for C-peptide immunoreactivity in the medial nucleus (B) and lateral hypothalamus (D), using an FITC-conjugated secondary antiserum. Double-labeled neurons are indicated by arrows. Calibration bar equals $100 \mu \mathrm{m}$. 
both substance $P$ - and tracer-containing neurons were sizable. Caudally, substance P-containing and retrogradely labeled neurons filled the medial subdivision as it extended ventrally to become the preoptic bed nucleus. At this level, $5-8 \%$ of the substance P-containing neurons observed were double labeled. Within the preoptic bed nucleus of the stria terminalis, however, substance $P$ immunoreactivity tapered off and no doublelabeled neurons were found.

Medial nucleus of the amygdala. The pattern of distribution of leumorphin-containing neurons in the mid-caudal to caudal medial amygdaloid nucleus overlapped considerably with the distribution of retrogradely labeled cell bodies. At mid-caudal levels, $4-8 \%$ of leumorphin-containing neurons were double labeled (Figs. 5B; 7A,B). Caudally, $7-11 \%$ of leumorphincontaining neurons were double labeled. At the caudal tip of the medial nucleus, leumorphin immunolabeling tapered off but retrogradely labeled neurons filled the nucleus. At this level, 2-3\% of the leumorphin-containing cell bodies were observed to be double labeled with retrograde tracer. Double-labeled neurons were located along the ventrolateral part of the nucleus at mid-caudal levels. The substantial population of leumorphin-containing cell bodies adjacent to the optic tract was completely devoid of retrograde labeling. At more caudal levels the double-labeled cells were found along the dorsolateral border of the nucleus.

The pattern of substance $P$ immunoreactivity in the mid-caudal and caudal regions of the medial nucleus was again similar to that of leumorphin immunoreactivity, overlapping considerably with retrograde labeling. In the mid-caudal medial nucleus $3-5 \%$ of the substance Pcontaining cell bodies were double labeled. These double-labeled neurons were situated ventrolateral within this region (Fig. 5D). Caudally, 2-3\% of the substance P-containing neurons analyzed were observed to be double labeled, located ventrally within the caudal medial nucleus. No double-labeled cell bodies were observed in the caudal tip of the medial nucleus.

In one animal with a control injection site centered in the preoptic bed nucleus of the stria terminalis (described below), several retrogradely labeled cell bodies were observed in the anterodorsal medial nucleus of the amygdala. The retrogradely labeled cell bodies observed in this area overlapped extensively with a population of leumorphin-containing neurons, and a much smaller population of substance P-containing neurons. In this animal, $4 \%$ of the leumorphin-containing neurons and $5 \%$ of the substance P-containing neurons in this more rostral area were double labeled. The proportions of double-labeled substance $\mathbf{P}$ - and leumorphin-containing neurons in the caudal posterodorsal subdivision in this animal were no different from those observed in animals with injection sites limited to the caudal medial preoptic area.

\section{Control results}

Immunocytochemistry. As reported previously ${ }^{43,44}$, both the substance $P$ and leumorphin antisera were highly specific for their peptide sequences. Only the rat C-terminus and substance $P$ peptides were able to block leumorphin and substance $P$ immunostaining, respectively. Other peptides had no effect. When KPBS was used in place of the primary antiserum, regardless of the fluorescent secondary antiserum used, no immunofluorescence was detected. Patterns of distribution of substance $\mathrm{P}$ and leumorphin immunoreactive cell bodies, fibers and terminals were identical in all hamster brains, with or without tracer injections.

Injection sites centered in other brain areas. Injection sites used for analysis in this study were confined to the medial half of the caudal one-third of the medial preoptic area. All injection sites confined to this location provided the characteristic retrograde labeling pattern described above. Injection sites centered in the rostral medial preoptic area or anterior hypothalamus produced different retrograde labeling patterns. Most notable from both sites was the absence of labeled cell bodies in the lateral septum, medial bed nucleus of the stria terminalis lateral hypothalamus and dorsal raphe.

One animal had an injection centered in the preoptic bed nucleus of the stria terminalis within the caudal extent of the medial preoptic area. In this animal, in addition to the usual sites of retrograde labeling observed in caudal medial preoptic area injections, projection neurons were observed in the mid-anterodorsal division of the medial nucleus of the amygdata as well as the posterodorsal subdivision.

Finally, in one animal the injection center was in the lateral half of the caudal medial preoptic area. In this animal the pattern of retrograde labeling was similar to that observed with medial sites. However, in this animal retrograde labeling was quantitatively less in most brain areas. In the medial nucleus of the amygdala there was still retrograde labeling in the caudal half, but retrogradely labeled cell bodies were observed more rostrally than in animals with medially confined sites. In this animal retrogradely labeled cell bodies were also observed in the core of the ventromedial nucleus of the hypothalamus, in contrast to the pattern observed with sites centered in the medial half of the medial preoptic area where labeling was confined to scattered neurons in the shell of the ventromedial nucleus, with none located in the core.

Double labeling in areas outside the bed nucleus and medial amygdaloid nucleus. Although the patterns of leumorphin- and substance P-containing projection neu- 
rons were similar to one another in the medial nucleus of the amygdala and bed nucleus of the stria terminalis, this was not the case in all areas of the brain. Observations from analysis of 3 other areas illustrate different patterns of results from those obtained in the amygdala and the bed nucleus.

The ventral lateral septum was an area which contained numerous retrogradely labeled neurons and numerous substance P- and leumorphin-containing cell bodies, yet this region contained no double-labeled neurons. After analysis of over 600 substance P-containing, 1100 leumorphin-containing and 2500 retrograde tracer-containing cell bodies from different parts of the ventral lateral septum of 6 animals with well placed injection sites, no double-labeled cell bodies from this area were observed.

The lateral hypothalamus was an area that contained a moderate number of retrogradely labeled neurons after injections into the caudal medial preoptic area, numerous leumorphin-containing neurons and no substance Pcontaining neurons. The pattern of retrograde labeling in the lateral hypothalamus was similar to what has been reported in the rat $^{5,57}$, with retrogradely labeled cell bodies extending laterally from the paraventricular nucleus towards the zona incerta in the rostral lateral hypothalamus (Fig. 7C,D) and disappearing caudally. These retrogradely labeled neurons extended over an area which also contained a population of prodynorphincontaining cell bodies ${ }^{44}$. At rostral and mid-caudal levels, from $7-10 \%$ of the leumorphin-containing neurons were retrogradely labeled (Fig. 5B). However, no substance P-containing neurons were located within the lateral hypothalamic area and, therefore, no substance Pcontaining projection neurons were identified in this area (Fig. 5D).

Lastly, the ventromedial nucleus of the hypothalamus contained a small number of distinct substance $\mathrm{P}$ immunolabeled neurons identified within the core. In addition, numerous lightly stained leumorphin-containing cell bodies were observed within the core and distinctly-labeled cell bodies in the shell of this nucleus. However, after tracer injections were centered into the medial half of the caudal medial preoptic area, no retrogradely labeled cell bodies were observed in the core of the ventromedial nucleus, and only an occasional retrogradely labeled neuron was observed in the shell region. Consequently no substance $\mathrm{P}$ - or leumorphin-containing neurons with projections to the medial portion of the caudal medial preoptic area were observed.

\section{DISCUSSION}

This study provides evidence for the existence of populations of substance P- and leumorphin (prodynorphin)-containing neurons within the medial bed nucleus of the stria terminalis and medial nucleus of the amygdala with efferent projections to the caudal one-third of the medial preoptic area in the male hamster brain. A population of prodynorphin-containing neurons within the lateral hypothalamus was also found to project to the medial preoptic area.

Dense prodynorphin- and substance P-containing fiber plexuses and terminals have been described within the medial preoptic area ${ }^{44,58}$. The results reported here indicate that at least a portion of these prodynorphincontaining fibers arise from the medial bed nucleus of the stria terminalis, medial amygdaloid nucleus and lateral hypothalamus, and a portion of the substance P-containing fibers arise from the medial bed nucleus and medial nucleus of the amygdala, but not from the lateral hypothalamus.

It should be noted, however, that there were several areas of the hamster brain that have projections to the medial preoptic area and that contain substance P- or leumorphin-immunoreactive neurons but were not analyzed in this study of the chemosensory pathway. These areas, the rostral medial preoptic area, arcuate nucleus of the hypothalamus, peripeduncular nucleus, dorsal raphe, central gray and several brainstem nuclei, may provide additional prodynorphin and substance $P$ input to the medial preoptic area. Paxinos and colleagues have demonstrated that knife cuts through the bed nucleus of the stria terminalis in the rat lead to the disappearance of substance P-like immunoreactivity in the medial preoptic area $^{47}$. However, these cuts extended from the bed nucleus of the stria terminalis to the base of the brain ventrally and may have severed substance P-containing

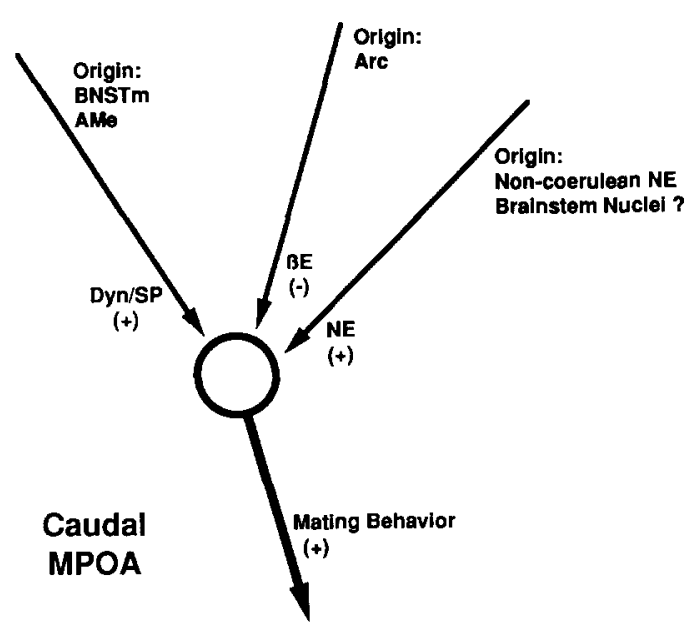

Fig. 8. Hypothetical model of neurotransmitters involved in the neural circuitry controlling male Syrian hamster mating behavior, showing possible interactions between $\beta$-endorphin, dynorphins, substance $\mathbf{P}$ and norepinephrine in the caudal medial preoptic area. 
inputs from other brain areas (i.e., the medial nucleus of the amygdala via the stria terminalis or the lateral hypothalamus via ascending medial forebrain bundle fibers $^{64}$ ).

Using lesion and immunohistochemistry techniques, Yamano and colleagues demonstrated a significant input to the medial preoptic area from substance P-containing neurons within the ventromedial nucleus of the hypothalamus of the male rat $^{64}$. This is in contrast to our findings in the hamster. As described above, we observed numerous leumorphin- and substance P-containing neurons within the core of the ventromedial nucleus, but no retrogradely labeled neurons were identified in this region. The most likely explanation for this discrepancy is that Yamano et al. ${ }^{64}$ may have injected the retrograde tracer into a larger area or different subdivision of the medial preoptic area than we did in this study. Their injection sites were not illustrated. The tracer injections used in the present analysis were confined to the medial part of the caudal medial preoptic area with the exception of one animal in which the injection was centered in the lateral part of this area. In that animal the injection did produce retrogradely labeled cells in the core of the ventromedial nucleus and in rostral levels of the medial nucleus of the amygdala.

This evidence for different circuits projecting to the medial versus the lateral part of the medial preoptic area is supported by recent anterograde tract tracing studies in this laboratory ${ }^{13}$. In these experiments, the posterodorsal medial nucleus of the amygdala was shown to project to the shell of the ventromedial nucleus of the hypothalamus and to the medial part of the caudal medial preoptic area while the anterodorsal subdivision of the medial nucleus projects to the core of the ventromedial nucleus and the lateral part of the caudal medial preoptic area. It is possible, therefore, that injections centered in the lateral portion of the caudal medial preoptic area in the hamster may retrogradely label these substance P-containing neurons within the core of the ventromedial nucleus as a part of a separate circuit connecting structures within the male hamster chemosensory pathway.

The projections to the medial preoptic area from the medial nucleus of the amygdala and medial bed nucleus of the stria terminalis demonstrated here are part of the neuroanatomical circuitry that controls male hamster mating behavior ${ }^{62,63}$. Bilateral lesions of these nuclei, or the fiber pathways connecting them, completely disrupt normal male mating behavior in the hamster ${ }^{30-32,51}$. The lateral hypothalamus, also shown here to project to the medial preoptic area, has not been identified as part of this excitatory chemosensory circuitry. Although earlier studies with knife cuts and electrolytic lesions suggested that it played a role in sexual behavior of the male rat $^{2,16,17}$, results of ibotenic acid lesions in this structure in the rat suggest that the effects in earlier studies were probably due to destruction of ascending tyrosine hydroxylase-positive (catecholaminergic) axons travelling through the area en route to the forebrain from the brainstem ${ }^{14,48}$.

Behavioral studies in the male rat have shown that placement of substance $\mathrm{P}$ or dynorphin $\mathrm{A}$ into the medial preoptic area facilitates mating behavior ${ }^{1,10}$. Results from the present study provide evidence that substance P- and prodynorphin-containing neurons located within the chemosensory pathway in the male hamster project to that part of the medial preoptic area in which lesions abolish mating behavior in this species ${ }^{51}$. These results are consistent with the hypothesis that both substance $P$ and prodynorphin peptides contribute to the chemosensory facilitation of this behavior. Studies to test this hypothesis directly in the hamster are needed.

The mechanism through which these peptides might influence male hamster sexual behavior is unknown. The results of the present study, however, can be considered in conjunction with observations of $\beta$-endorphinergic projections to the medial preoptic area from the arcuate nucleus of the hypothalamus ${ }^{45}$ to propose a model for neurotransmitter control of this behavior (Fig. 8). In this scheme, the substance $P$ and dynorphinergic inputs from the bed nucleus of the stria terminalis and medial nucleus of the amygdala facilitate copulatory behavior through an interaction with $\beta$-endorphin input from the arcuate nucleus which inhibits the behavior. This model, although purely hypothetical, can be supported on the following bases.

$\alpha$-Adrenergic receptors in the medial preoptic area ${ }^{33,65}$ and noradrenergic projections to this area from the $\mathrm{Al}$ and $\mathrm{A} 2$ cell groups in the medulla have been described ${ }^{8}$. This noradrenergic system has been implicated as a facilitator for normal copulatory behavior in the rat $^{3,6,7}$. Pharmacological and anatomical experiments also support the notion that noradrenergic input to the medial preoptic area facilitates the release of gonadotropinreleasing hormone $(\mathrm{GnRH})^{23,25,34}$. In contrast, the endogenous opioid $\beta$-endorphin is inhibitory not only to GnRH release ${ }^{26}$, but also to mating behavior in both the rat and hamster ${ }^{37,41}$, the latter apparently via interactions in the caudal medial preoptic area ${ }^{19}$. These inhibitory effects of $\beta$-endorphin may be via direct inhibition of the noradrenergic input, a mechanism that is supported by both pharmacological ${ }^{24,26}$ and ultrastructural observations ${ }^{4}$.

Dynorphin and substance $P$ in this system are less well studied than $\beta$-endorphin and norepinephrine. Although the neurophysiological effects of dynorphin and sub- 
stance $P$ on neurons within the medial preoptic area are not known, both of these peptides have been shown to facilitate male sexual behavior when released into the medial preoptic area ${ }^{1,10}$. Based on data from other laboratories demonstrating that substance $\mathrm{P}$ can induce the release of Met-enkephalin and possibly dynorphins from nerve terminals in the striatum and spinal cord, we hypothesize here that substance $P$ may act presynaptically to facilitate release of dynorphins from nerve terminals in the medial preoptic area ${ }^{9,59}$. This is not dependent upon, but is consistent with, colocalization of these two peptides in the same terminal ${ }^{43}$.

Thus, in this model substance $P$ induces the release of prodynorphin peptides in the caudal medial preoptic area. These prodynorphin peptides facilitate mating behavior by inhibiting the inhibitory influence of $\beta$ endorphin on previously existing noradrenergic facilitation. North ${ }^{46}$ has suggested, based on ion conductance studies of the opioid receptor types found in the brain, that activation of $\mu, \delta$ or $\kappa$ opioid receptors can, under certain conditions, lead to reduction in transmitter release from, or an inhibition of firing of, nerve cells bearing those receptors. In support of this notion, Mulder and colleagues have demonstrated that dynorphin [1-8] and [1-13], via their high affinity for kappa receptors, mediate presynaptic inhibition of electricallyinduced release of dopamine, acetylcholine and norepinephrine from rat brain slices ${ }^{40}$.

Observations of the effects of castration on these transmitters and on behavior are also consistent with the model in Fig. 8. There is evidence that all 3 of these peptide projection systems are under gonadal steroid control. Arcuate nucleus $\beta$-endorphin content has been shown to increase after castration and return to normal upon testosterone replacement ${ }^{52}$. In contrast, castration

$\begin{array}{ll}\text { ABBREVIATIONS } \\ \text { ac } & \text { anterior commissure } \\ \text { ADPN } & \text { anterodorsal preoptic nucleus } \\ \text { AH } & \text { anterior hypothalamus } \\ \text { AHA } & \text { amygdalohippocampal area } \\ \text { alac } & \text { anterior limb of the anterior commissure } \\ \text { ACe } & \text { central nucleus of the amygdala } \\ \text { ACo } & \text { anterior cortical nucleus of the amygdala } \\ \text { AMe } & \text { medial nucleus of the amygdala } \\ \text { Arc } & \text { arcuate nucleus of the hypothalamus } \\ \text { BLa } & \text { basolateral nucleus of the amygdala } \\ \text { BM } & \text { basomedial nucleus of the amygdala } \\ \text { BNST1 } & \text { lateral bed nucleus of the stria terminalis } \\ \text { BNSTm } & \text { medial bed nucleus of the stria terminalis } \\ \text { BNSTV } & \text { ventral bed nucleus of the stria terminalis } \\ \text { cp } & \text { cerebral peduncle } \\ \text { DMH } & \text { dorsomedial nucleus of the hypothalamus } \\ \text { f } & \text { fornix } \\ \text { GP } & \text { globus pallidus } \\ \text { III } & \text { third ventricle } \\ \text { LH } & \text { lateral hypothalamus }\end{array}$

induces a loss of substance $\mathrm{P}^{58}$ and prodynorphin (unpublished observations) immunoreactivity in the bed nucleus of the stria terminalis and medial nucleus of the amygdala in the male hamster, both of which are reversed with testosterone replacement. In addition, both $\beta$-endorphin- and dynorphin-containing cell bodies that actively accumulate circulating gonadal steroids have been identified ${ }^{39}$.

This study provides evidence that neuropeptides implicated in the regulation of sexual behavior in the hamster and rat are actually present in the chemosensory circuitry which controls this behavior in the male Syrian hamster. Investigation of the impact of these leumorphin and substance $\mathbf{P}$ inputs into the medial preoptic area may be accomplished through immunohistochemical labeling after lesions of the medial bed nucleus of the stria terminalis or medial nucleus of the amygdala, through ultrastructural studies of the relationship of chemically identified synapses and via analysis of the regulation of these peptides by circulating gonadal steroids. It will also be helpful to demonstrate the facilitation of sexual behavior with injections of dynorphin or substance $P$ peptides directly into the parenchyma of male hamster medial preoptic area, as has been demonstrated in the rat. These and other studies will be necessary in the evaluation of this proposed model system.

Acknowledgements. We wish to thank Dr. Stanley J. Watson, Jr. for generously providing us with antisera for this study. We also would like to thank Drs. Fred Karsch and J. Bradley Powers for critical review of the manuscript. The morphology core of the Reproductive Sciences Program provided valuable technical assistance, supported by 1-P30-HD-18258. This work was supported by NIH grant NS-20629 to S.W.N. and NIGMS grant GM-10341 to C.R.N.J.

$\begin{array}{ll}\text { LV } & \text { lateral ventricle } \\ \text { LSV } & \text { ventral lateral septum } \\ \text { MePO } & \text { median preoptic nucleus } \\ \text { MPN } & \text { medial preoptic nucleus } \\ \text { MPNmag } & \text { magnocellular medial preoptic nucleus } \\ \text { MPOAH } & \text { medial preoptic anterior hypothalamic area } \\ \text { mt } & \text { mammillothalamic tract } \\ \text { oc } & \text { optic chiasm } \\ \text { ot } & \text { optic tract } \\ \text { PLCo } & \text { posterolateral cortical nucleus of the amygdala } \\ \text { PMCo } & \text { posteromedial cortical nucleus of the amygdala } \\ \text { PT } & \text { parataenial nucleus of the thalamus } \\ \text { PVN } & \text { paraventricular nucleus of the hypothalamus } \\ \text { SCN } & \text { suprachiasmatic nucleus of the hypothalamus } \\ \text { sm } & \text { stria medullaris } \\ \text { St } & \text { stria terminalis } \\ \text { VMH } & \text { ventromedial nucleus of the hypothalamus } \\ \beta E & \beta \text {-endorphin } \\ \text { Dyn } & \text { dynorphin } \\ \text { Leum } & \text { leumorphin } \\ \text { NE } & \text { norepinephrine } \\ \text { SP } & \text { substance P }\end{array}$




\section{REFERENCES}

1 Band, L. and Hull, E., Opioids microinjected into central dopaminergic pathways: effects on copulation in male rats, Soc. Neurosci. Abstr., 14 (1988) 293.

2 Caggiula, A.R., Antelman, S.M., and Zigmond, M.J., Disruption of copulation in male rats after hypothalamic lesions: a behavioral, anatomical and neurochemical analysis, Brain Research, 59 (1973) 273-287.

3 Caggiula, A.R., Shaw, D.S., Antelman, S.M. and Edwards, D.J., Interactive effects of brain catecholamines and variations in sexual and non-sexual arousal on copulatory behavior of male rats, Brain Research, 111 (1976) 321-336.

4 Chen, W.-P., Witkin, J.W. and Silverman, A.-J., Beta-endorphin and gonadotropin releasing hormone synaptic input to gonadotropin releasing hormone neurosecretory cells in the male rat, J. Comp. Neurol., 286 (1989) 85-95.

5 Chiba, T. and Murata, Y., Afferent and efferent connections of the medial preoptic area in the rat: a WGA-HRP study, Brain Res. Bull., 14 (1985) 261-272.

6 Clark, J.T., Smith, E.R. and Davidson, J.M., Enhancement of sexual motivation in male rats by yohimbine, Science, $225(1984)$ 847-849.

7 Clark, J.T., Smith, E.R. and Davidson, J.M., Evidence for the modulation of sexual behavior by alpha-adrenoreceptors, $\mathrm{Neu}$ roendocrinology, 41 (1985) 36-43.

8 Day, T.A., Blessing, W. and Willoughby, J.O., Noradrenergic and dopaminergic projections to the medial preoptic area of the rat. A combined horseradish peroxidase/catecholamine fluorescence study, Brain Research, 193 (1980) 543-548.

9 Del Rio, J., Naranjo, J.R., Yang, H.-Y.T. and Costa, E., Substance $P$ induced release of met $^{5}$-enkephalin from striatal and periaqueductal gray slices, Brain Research, 279 (1983) 121-126.

10 Dornan, W.A. and Malsbury, C.W., Neuropeptides and male sexual behavior, Neurosci. Behav. Rev., 13 (1989) 1-15.

11 Dorsa, D.M. and Smith, E.R., Facilitation of mounting behavior in male rats by intracranial injections of luteinizing hormonereleasing hormone, Regul. Pept., 1 (1980) 147-155.

12 Fallon, J.H. and Leslie, F.M., Distribution of dynorphin and enkephalin peptides in the rat brain, J. Comp. Neurol., 249 (1986) 293-336.

13 Gomez, D.M., Differential projections of the anterior and posterior regions of the medial amygdaloid nucleus and the anterior amygdaloid area in the Syrian hamster using the anterograde neuronal tracer,Phaseolus vulgaris Leucoagglutin, J. Comp. Neurol., submitted

14 Hanson, S., Kohler, Ch., Goldstein, M. and Steinbusch, H.M.V., Effects of ibotenic acid-induced neuronal degeneration in the medial preoptic area and the lateral hypothalamic area on sexual behavior in the male rat, Brain Research, 239 (1982) 213-232.

15 Heimer, L. and Larsson, K., Impairment of mating behavior in male rats following lesions in the preoptic-anterior hypothalamic continuum, Brain Research, 3 (1967) 248-263.

16 Hitt, J.C., Hendricks, S.E., Ginsberg, S.I. and Lewis, J.H., Disruption of male, but not female, sexual behavior in rats by medial forebrain bundle lesions, J. Comp. Physiol. Psychol., 73 (1970) 377-384.

17 Hitt, J.C., Bryon, D.M. and Modianos, D.T., Effects of rostral medial forebrain bundle and olfactory tubercle lesions upon sexual behavior of male rats, J. Comp. Physiol. Psychol., 82 (1973) 30-36.

18 Hollander, H., Egensperger, R. and Dirlich, G., Size distribution of rhodamine-labeled microspheres retrogradely transported in cultured neurons, J. Neurosci. Methods, 29 (1989) 1-4.

19 Hughes, A.M., Everitt, B.J. and Herbert, J., Selective effects of $\beta$-endorphin infused into the hypothalamus, preoptic area and bed nucleus of the stria terminalis on the sexual and investigative behavior in male rats, Neuroscience, 23 (1987) 1063-1073.
20 Imura, H., Kato, Y., Nakai, K., Nakao, K., Tanaka, I., Jingami, H., Koh, T., Yoshimasa, Y., Tsukada, T., Suda, M., Sakamoto, M., Morii, N., Takahashi, H., Tojo, K. and Sugawara, A. Endogenous opioids and related peptides: from molecular biology to clinical medicine. The Sir Henry Dale Lecture for 1985, J. Endocrinol., 107 (1985) 147-157.

21 Johnson, G.D. and de C. Nogueira Araujo, G.M., A simple method of reducing fading of immunofluorescence during microscopy, J. Immunol. Methods, 43 (1981) 349-350.

$22 \mathrm{Ju}, \mathrm{G}$., Han, Z and Fan, L., Fluorogold as a retrograde tracer used in combination with immunohistochemistry, $J$. Neurosci. Methods, 29 (1989) 69-72.

23 Kalra, S.P. and Simpkins, J.W., Evidence for noradrenergic mediation of opioid effects on leuteinizing hormone secretion, Endocrinology, 109 (1981) 776-782

24 Kalra, S.P. and Gallo, R.V., Effects of intraventricular catecholamines on leuteinizing hormone release in morphine-treated rats, Endocrinology, 113 (1983) 23-28.

25 Kalra, S.P. and Kalra, P.S., Neural regulation of leuteinizing hormone secretion in the rat, Endocrinol. Rev. 4 (1983) 311-351.

26 Kalra, S.P. and Kalra, P.S., Opioid-adrenergic-steroid connection in regulation of leuteinizing hormone secretion in the rat, Neuroendocrinology, 38 (1984) 418-426.

$27 \mathrm{Katz}$, L.C., Burkhalter, A. and Dreyer, W.J., Fluorescent latex microspheres as a retrograde neuronal marker for in vivo and in vitro studies of visual cortex, Nature, 310 (1984) 498-500.

$28 \mathrm{Katz}$, L.C. and Iarovici, D.M., Green fluorescent latex microspheres: a new retrograde tracer, Soc. Neurosci. Abstr., 14 (1988) 548.

29 Kevetter, G.A. and Winans, S.S., Connections of the corticomedial amygdala in the golden hamster, I. Efferents of the 'vomeronasal amygdala', J. Comp. Neurol., 197 (1981) 81-98.

30 Lehman, M.N., Winans, S.S. and Powers, J.B., Medial nucleus of the amygdala mediates chemosensory control of male hamster sexual behavior, Science, 210 (1980) 557-560.

31 Lehman, M.N., Powers, J.B. and Winans, S.S., Stria terminalis lesions alter the temporal pattern of copulatory behavior in the male golden hamster, Behav. Brain Res., 8 (1983) 109-128.

32 Lehman, M.N. and Winans, S.S., Evidence for a ventral non-strial pathway from the amygdala to the bed nucleus of the stria terminalis in the male golden hamster, Brain Research, 268 (1983) 139-146.

33 Leibowitz, S.F., Jhanwar-Uniyal, M., Dvorkin, B. and Makman, M.H., Distribution of $\alpha$-adrenergic and $\beta$-adrenergic and dopaminergic receptors in discrete hypothalamic areas of rat, Brain Research, 233 (1982) 97-114.

34 Leranth, C., MacLusky, N.J., Shanabrough, M. and Naftolin, F., Catecholaminergic innervation of leuteinizing hormonereleasing hormone and glutamic acid decarboxylase immunopositive neurons in the rat medial preoptic area, Neuroendocrinology, 48 (1988) 591-602.

35 Maragos, W.F., Newman, S.W., Lehman, M.N. and Powers, J.B., Neurons of origin and fiber trajectory of amygdalofugal projections to the medial preoptic area in the Syrian hamster, $J$. Comp. Neurol., 280 (1989) 59-71.

36 Meyerson, B.J., Neonatal $\beta$-endorphin and sexual behavior, Acta Physiol. Scand., 115 (1982) 159-160.

37 Meyerson, B.J. and Terenius, L., $\beta$-Endorphin and male sexual behavior, Eur. J. Pharmacol, 42 (1977) 191-192.

38 Mitchell, J.B. and Stewart, J. Facilitation of sexual behaviors in the male rat associated with intra-VTA injections of opiates, Pharmacol. Biochem. Behav., 35 (1990) 643=650.

39 Morrell, J.I., McGinty, J.F. and Pfaff, D.W., A subset of $\beta$-endorphin- or dynorphin-containing neurons in the medial basal hypothalamus accumulates estradiol, Neuroendocrinology, 41 (1985) 417-426.

40 Mulder, A.H., Wardeh, G., Hogenboom, F. and Frankhuyzen, L., Selectivity of various opioid peptides towards delta-, kappaand mu-opioid receptors mediating presynaptic inhibition of 
neurotransmitter release in the brain, Neuropeptides, 14 (1989) 99-104.

41 Murphy, M.R., Bowie, D.L., and Pert, C., Copulation elevates plasma $\beta$-endorphin in the male hamster, Soc. Neurosci. Abstr., 5 (1979) 470.

42 Murphy, M.R., Methadone reduces sexual performance and sexual motivation in the male golden hamster, Pharmacol. Biochem. Behav., 14 (1981) 561-567.

43 Neal, Jr. C.R., Newman, S.W. and Swann, J.M., The colocalization of substance $\mathrm{P}$ and prodynorphin immunoreactivity in neurons of the medial preoptic area, bed nucleus of the stria terminalis and medial nucleus of the amygdala of the Syrian hamster, Brain Research, 496 (1989) 1-13.

44 Neal, Jr., C.R. and Newman, S.W., Prodynorphin peptide distribution in the forebrain of the Syrian hamster and rat: a comparative study with antisera against dynorphin $\mathrm{A}$, dynorphin $\mathrm{B}$ and the C-terminus of the prodynorphin precursor molecule, J. Comp. Neurol., 288 (1989) 353-386.

45 Neal, Jr., C.R. and Newman, S.W., Proopiomelanocortin distribution in the male Syrian hamster brain and beta-endorphinergic projections from the arcuate nucleus of the hypothalamus to the medial preoptic area, J. Comp. Neurol., submitted.

46 North, A., Opioid receptor types and membrane ion channels, Trends Neurosci., May (1986) 114-117.

47 Paxinos, G., Emson, P.C. and Cuello, C., Substance P projections to the entopeduncular nucleus, the medial preoptic area and the lateral septum, Neurosci. Lett., 7 (1978) 133-136.

48 Peterson, G.M. and Moore, R.Y., Selective effects of kainic acid on diencephalic neurons, Brain Research, 202 (1980) 165-182.

49 Pieribone, V.A. and Aston-Jones, G., The iontophoretic application of Fluoro-gold for the study of afferents to deep brain nuclei, Brain Research, 475 (1988) 259-271.

50 Platt, J.L. and Michael, A.F., Retardation of fading and enhancement of intensity of immunofluorescence by $p$-phenylenediamine, J. Histochem. Cytochem., 31 (1983) 840-842.

51 Powers, J.B., Newman, S.W. and Bergondy, M.L., MPOA and BNST lesions in the male Syrian hamster: differential effects on copulatory and chemoinvestigatory behaviors, Behav. Brain Res., 23 (1987) 181-195.

52 Roberts, A.C., Martensz, N.D., Hastings, M.H. and Herbert, J., The effects of castration, testosterone replacement and photoperiod upon hypothalamic $\beta$-endorphin levels in Syrian hamster, Neuroscience, 23 (1987) 1070-1082.

53 Sakuma, Y. and Akaishi, T., Leumorphin, a novel opioid peptide, promotes lordosis in female rats, Brain Research, 407 (1987) 401-404.
54 Schmued, L.C. and Fallon, J.H., Fluoro-gold: a new fluorescent retrograde axonal tracer with numerous unique properties, Brain Research, 377 (1986) 147-154.

55 Shimada, S., Inagaki, S., Kubota, Y., Kito, S., Shiotani, Y. and Tohyama, M., Coexistence of substance $P$ and enkephalin-like peptides in single neurons of the rat hypothalamus, Brain Research, 425 (1987) 256-262.

56 Shimada, S., Inagaki, S., Kubota, Y., Kito, S., Shiotani, Y. and Tohyama, M., Coexistence of substance $P$ and neurotensin-like peptides in single neurons of the rat hypothalamus, Peptides, 9 (1988) 71-76.

57 Simerly, R.B. and Swanson, L.W., The organization of neural inputs to the medial preoptic nucleus of the rat., J. Comp. Neurol., 246 (1986) 312-342.

58 Swann, J.M. and Newman, S.W., Effect of castration and testosterone treatment on substance $P$ levels within the vomeronasal pathway of the male golden hamster, Soc. Neurosci. Abstr., 13 (1987) 1576.

59 Tang, J., Chou, J., Yang, H.-Y.T. and Costa, E., Substance P stimulates the release of met ${ }^{5}$-enkephalin and met ${ }^{5}$-enkephalinarg $^{6}-$ phe $^{7}$ from rat spinal cord, Neuropharmacology, 22 (1983) $1147-1150$

60 Vijayan, E. and McCann, S.M., In vivo and in vitro effects of substance $P$ and neurotensins on gonadotropin and prolactin release, Endocrinology, 105 (1979) 64-68.

61 Wessendorf, M.W., Appel, N.M. and Elde, R., Simultaneous observation of fluorescent retrogradely labeled neurons and the immunofluorescently labeled fibers apposing them using Fluorogold and antisera labeled with the blue fluorochrome 7 amino-4-methylcoumarin-3-acetic acid (AMCA), Neurosci. Lett., 82 (1987) 121-126.

62 Winans, S.S. and Powers, J.B., Olfactory and vomeronasal deafferentation of male hamsters: histological and behavioral analyses, Brain Research, 126 (1977) 325-344.

63 Winans, S.S., Lehman, M.N. and Powers, J.B., Vomeronasal and olfactory CNS pathways which control male hamster mating behavior. In: W. Breipohl (Ed.), Olfaction and Endocrine Regulation, 1982, IRL Press, London, pp. 23-34.

64 Yamano, M., Inagaki, S., Kito, S. and Tohyama, M. A substance P-containing pathway from the hypothalamic ventromedial nucleus to the medial preoptic area of the rat: an immunohistochemical analysis, Neuroscience, 18 (1986) 395402.

65 Young, S.W. and Kuhar, M.J., Noradrenergic $\alpha 1$ and $\alpha 2$ receptors: light microscopic audoradiographic localization, Proc. Natl. Acad. Sci. U.S.A., 77 (1980) 1696-1700. 